BIOTROPIA No. 3, 1989/1990: 41-49

\title{
ANTAGONISTIC EFFECT OF FOUR FUNGAL ISOLATES TO GANODERMA BONINENSE, THE CAUSAL AGENT OF BASAL STEM ROT OF OIL PALM
}

\author{
OKKY SETYAWATIDHARMAPUTRAand H.S. SOETARMITJIIROSOMO \\ SEAMEO-BIOTROP, P.O. Box 17, Bogor, Indonesia \\ ABDULLATIEFABADI \\ Faculty of Agriculture, Brawijaya University, Malang, Indonesia
}

\begin{abstract}
Four fungal isolates from soils obtained from three sites of the oil palm plantations in North Sumatra were found antagonistic to Ganoderma boninense, the causal agent of basal stem rot of oil palm. Penicillium citrinum inhibited the growth of the pathogen and formed a zone of inhibition on the agar media. Trichoderma harzianum BIO - 1 as well as BIO - 2 and T. viride not only repressed the growth of the pathogen but also caused lysis of the hyphae, and the colony was totally overgrown by the antagonists.
\end{abstract}

\section{INTRODUCTION}

Ganoderma boninense Pat. is an important basal stem rot pathogen of oil palm (Elaeis guineensis Jacq.) in North Sumatra. Some control methods have been applied to overcome the disease but none seemed to be satisfactory (Parnata 1974; Suyoto \& Djamin 1981; Sipayung \& Purba 1986).

The use of antagonistic soil microorganisms to control the pathogen has not been investigated so far. Taking into consideration the statement asserted by Cook \& Baker (1983) that certain species of Penicillium and Trichoderma have been reported to be antagonistic to plant pathogenic fungi, we at BIOTROP were curious to find out whether some antagonists could be isolated from soil samples taken from the oil palm plantations in North Sumatra and investigate their antagonistic properties against Ganoderma boninense. This paper describes the results of an investigation on the effect of four fungal isolates on the growth of the pathogen in vitro.

\section{MATERIALS AND METHODS}

\section{Isolation of fungi from soil}

Soil samples were taken randomly from three locations (Adolina, Gunung Bayu, and Tinjowan) of the oil palm plantations in North Sumatra. The dilution 
plate method (Johnson \& Curl 1972) was used to isolate the fungi at a concentration of $10^{-2} \mathrm{ml}$. Into each Petri dish, $1 \mathrm{ml}$ of the soil suspension was transferred aseptically and added to it was $10-12 \mathrm{ml}$ of melted selective medium containing chloramphenicol and rose bengal. The dishes were then incubated for 5 days at room temperature.

\section{Isolates of $G$. boninense}

Isolates of G. boninense used in this experiment were GA, GB and GD. They were isolated from basidiocarps obtained from the basal stem of oil palm in North Sumatra. The name of the isolates were based on the colour and morphology of the basidiocarp.

\section{Antagonism between G. boninense isolate GB and the fungal isolates}

The fungal isolates obtained were tested for their antagonistic property against the pathogen using the direct opposition method as recommended by Dennis \& Webster (1971). The promising antagonistic molds were then put aside for further studies.

The direct opposition method was prepared by placing the pathogen $(4 \mathrm{~mm}$ in diameter) on the PDA medium and 2 days later at a distance of $3 \mathrm{~cm}$ from the pathogen the antagonist was inoculated on the same dish (Figure 1). Each treatment was in three replications and incubated at room temperature.

Observations were made on the growth of the pathogen and the presence of an inhibition zone that might develop between the two colonies (Figure 2).

\section{Antagonism between G. boninense isolates GA, GB and GD and the four promising isolates of fungi}

In this study the four isolates of fungi that were found antagonistic to the pathogen were further tested individually for their effect on the pathogen when placed together using the direct opposition method.

The inoculation method of the pathogen and the antagonist is the same as previously mentioned. Observations were made 3 days after the inoculation of the antagonists on the inhibition of mycelial growth of the pathogen by the antagonist using the formula of Fokkema (1973):

$$
\mathrm{I}=\frac{\mathrm{r}_{1}-\mathrm{r}_{2}}{\mathrm{r}_{1}} \times 100 \%
$$

where $\mathrm{I}=$ percentage of inhibition

$\mathrm{r}_{1}=$ radius of the pathogen away from the antagonist

$r_{2}=$ radius of the pathogen towards the antagonist 
Antagonistic effect of four fungal isolates-O.S. Dharmaputra, H.S.S. Tjitrosomo \& A.L. Abadi

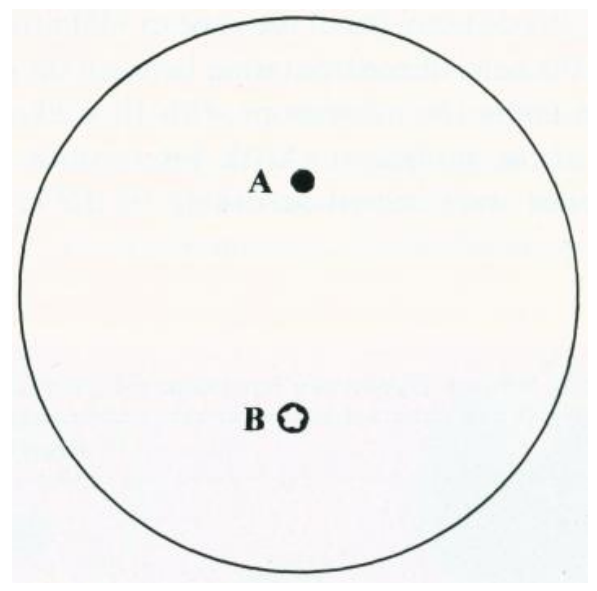

Figure 1. Antagonistic test between G. boninense and the fungal isolate. A, inoculum of G. boninense; B, inoculum of the fungal isolate tested.

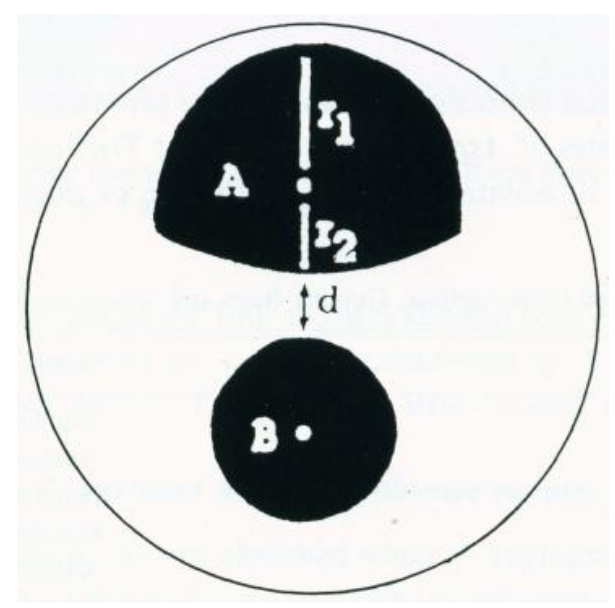

Figure 2. Colony measurement of G. boninense (A) to calculate the percentage of inhibition by the antagonist (B). Radius of the pathogen ( $r$, and $r_{2}$ ) and the zone of inhibition (d) were also noted. 
For $P$. citrinum, the distance (d) of the zone of inhibition was also measured. Hyphal interaction in the zone of confrontation between the colonies was observed by direct examination under the microscope with $10 \times 200$ magnification 2 days after the inoculation of the antagonist (AIA). Interactions observed between the pathogen and antagonist were scored according to the categories presented in Table 1.

Table 1. Score of interaction between Ganoderma boninense and Trichoderma.

\begin{tabular}{cc}
\hline Score & Criteria/pathogen hyphae lysed \\
\hline 1 & \multicolumn{1}{c}{ $\pm 25 \%$} \\
3 & $\pm 50 \%$ \\
The scores were added by 1 & $\pm 90 \%$ \\
& If pathogen hyphae were \\
The scores were reduced & smaller than the normal ones \\
by $1 / 2$ & If $\pm 10 \%$ of the antagonist \\
The scores were reduced by 1 & hyphae were also lysed \\
& If $\pm 25 \%$ of the antagonist \\
& Hyphae were also lysed \\
\hline
\end{tabular}

\section{RESULTS AND DISCUSSION}

The fungi isolated from the soil samples are presented in Table 2: 4 isolates of Penicillium, 2 isolates of Aspergillus, 3 isolates of Trichoderma, and 1 unidentified isolate, totaling 10 isolates obtained by the use of dilution plate method.

Table 2. The fungi isolated from Adolina, Gunung Bayu and Tinjowan, North Sumatra.

\begin{tabular}{rll}
\hline \hline No. & Fungal isolate & Origin of the soil sample \\
\hline 1. & Penicillium sp. 1 & Adolina, Tinjowan \\
2. & Penicillium sp. 2 & Adolina, Tinjowan \\
3. & Penicillium sp. 3 & Adolina, Tinjowan \\
4. & Penicillium sp. 4 & Gunung Bayu, Tinjowan \\
5. & Aspergillus sp. 1 & Adolina, Gunung Bayu \\
6. & Aspergillus sp. 2 & Gunung Bayu, Tinjowan \\
7. & Trichoderma sp. 1 & Gunung Bayu, Tinjowan \\
8. & Trichoderma sp. 2 & Adolina \\
9. & Trichoderma sp. 3 & Gunung Bayu \\
10. & Unidentified & Adolina, Gunung Bayu \\
\hline
\end{tabular}


Cook and Baker (1983) stated that Penicillium and Trichoderma have long been recognized as antagonists to plant pathogenic fungi. All of the ten isolates obtained were further tested on the possibility of inhibiting the growth of the pathogen (isolate GB) in vitro using the direct opposition method as recommended by Dennis \& Webster (1971). Of the 10 isolates, only four showed promising result, that is Penicillium sp. 2, Trichoderma sp. 1, Trichoderma sp. 2, and Trichoderma sp. 3 (Figure 3).

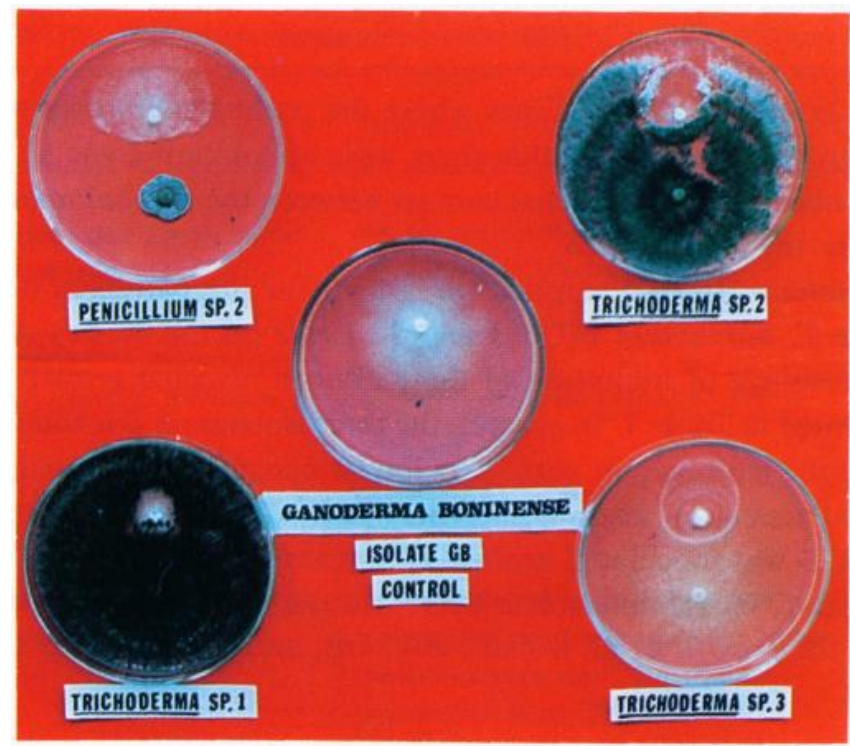

Figure 3. Antagonism between Ganoderma boninense isolate GB and Penicillium sp. 2, Trichoderma sp. 1, Trichoderma sp. 2 and Trichoderma sp. 3.

Further identification of the four isolates showed that Penicillium sp. 2, Trichoderma sp. 1, Trichoderma sp. 2, and Trichoderma sp. 3 were respectively $P$. citrinum, T. harzianum BIO-1, T. harzianum BIO-2 and T. viride.

\section{Antagonism between P. citrinum and G. boninense isolates GA, GB, and GD}

A zone of inhibition (d) was observed when P. citrinum was paired with the pathogen. The growth of the pathogen towards the antagonist was inhibited since the $2^{\text {nd }}$ day AIA and it stopped to grow on the $6^{\text {th }}$ day AIA. The distance (d) of the zone of inhibition on the $3^{\text {rd }}$ day AIA were $11.25 \mathrm{~mm}, 12.88 \mathrm{~mm}$ and $10.88 \mathrm{~mm}$ for isolates GA, GB and GD, respectively. It was assumed that an antibiotic diffused into the medium. 
Statistical analysis using $\mathrm{F}$ indicated that I on the $3^{\text {rd }}$ day AIA was not significantly different among the three isolates of the pathogen: $29.95 \%$ for isolate GA, $25.28 \%$ for isolate GB and $19.08 \%$ for isolate GD, respectively.

Direct examination under the microscope showed that the hyphae of the pathogen were not lysed, but they were abnormal, i.e. they had more septa and their cells were shorter than the normal ones.

\section{Antagonism between Trichoderma isolates and G. boninense isolates GA, GB and GD}

Having examined all the dishes where the pathogen colonies and the antagonists were grown, it was noted that there were no inhibition zones. For all treatments, it was observed that mycelial contact between the two colonies on the same dish started on the $2^{\text {nd }}$ day AIA.

T. harzianum BIO - 2 stopped the growth of the pathogen on the $3^{\text {rd }}$ day AIA, whereas $T$. harzianum BIO- 1 and $T$. viride on the $4^{\text {th }}$ day AIA.

The percentage of inhibition of the pathogen mycelial growth by the antagonist is presented in Table 3. In general, the three isolates of Trichoderma inhibited the growth of the pathogen in vitro. The lowest percentage occurred when isolate GB was placed against $T$. harzianum isolate BIO-2, while the highest was noted when isolate GD was inoculated against T. harzianum BIO-2. It is interesting to report here that T. harzianum isolate BIO - 1 was able to inhibit at statistically the same degree, the growth of all isolates GA, GB, and GD, whereas the inhibition

Table 3. Average percentage inhibition of mycelial growth of Ganoderma boninense isolate GA, GB and GD by Trichoderma harzianum (isolate $\mathrm{BIO}$ - 1 and $\mathrm{BIO}$ - 2) and T. viride.

Combination of treatment

(Pathogen vs. antagonist)

\begin{tabular}{|c|c|}
\hline $\begin{array}{l}\text { Ganoderma boninense vs. Trichoderma harzianum } \\
\text { isolate GB } \\
\text { isolate } \mathrm{BIO}-2\end{array}$ & $28.96 \mathrm{a}$ \\
\hline G. boninense isolate GD vs. T. viride & $37.71 \mathrm{~b}$ \\
\hline G. boninense isolate GB vs. T. viride & $38.57 \mathrm{~b}$ \\
\hline G. boninense isolate GA vs. T. harzianum isolate $\mathrm{BIO}-1$ & 39.53 be \\
\hline G. boninense isolate GA vs. T. harzianum isolate BIO-2 & 39.62 be \\
\hline G. boninense isolate GD vs. T. harzianum isolate BIO- 1 & 40.29 be \\
\hline G. boninense isolate GB vs. T. harzianum isolate BIO- 1 & 41.57 be \\
\hline G. boninense isolate GA vs. T. viride & 41.84 be \\
\hline G. boninense isolate GD vs. T. harzianum isolate BIO-2 & $45.18 \mathrm{c}$ \\
\hline
\end{tabular}

Average of inhibition*)

(\%)

28.96

$37.71 \mathrm{~b}$

39.62 be

41.84 be

46 
of T. harzianum BIO - 2 and T. viride was determined by the type of isolate of the pathogen.

Direct examination under the microscope showed that the pathogen hyphae underwent lysis; the percentage of which was determined by the type of isolate of the antagonist (Table 4). In any case, the hyphae of the antagonist were also lysed in certain treatment, e.g. T. harzianum BIO- 1 vs. G. boninense isolates GA and

Table 4. Microscopic examination of hyphal interaction between Ganoderma boninense isolates GB and GD with Trichoderma harzianum (isolates BIO -1 and BIO - 2) and T. viride.

\begin{tabular}{|c|c|c|}
\hline $\begin{array}{l}\text { Combination of treatment (Pathogen vs. } \\
\text { antagonist) }\end{array}$ & Description & $\begin{array}{c}\text { Effectivity score } \\
\text { of antagonist }\end{array}$ \\
\hline
\end{tabular}

Ganoderma boninense isolate GA vs. Trichoderma harzianum isolate $\mathrm{BIO}-1$

G. boninense isolate GB vs. T. harzianum isolate $\mathrm{BIO}-1$

G. boninense isolate GD vs. T. harzianum isolate $\mathrm{BIO}-1$

G. boninense isolate GA vs. $T$. harzianum isolate $\mathrm{BIO}-2$

G. boninense isolate GB vs. T. harzianum isolate $\mathrm{BIO}-2$

G. boninense isolate GD vs. T. harzianum isolate $\mathrm{BIO}-2$

G. boninense isolate GA vs. $T$. viride

G. boninense isolate $\mathrm{GB}$ vs. $T$. viride

G. boninense isolate GD. vs. $T$. viride
G. boninense hyphae lysed about $90 \%$

T. harzianum hyphae lysed about $10 \%$

$21 / 2$

G. boninense hyphae lysed about $90 \%$

3

G. boninense hyphae lysed about $90 \%$

$21 / 2$

T. harzianum hyphae lysed about $10 \%$

G. boninense hyphae lysed about $50 \%$
starting from the tip of hyphae, the hyphae tended to become small. $T$. harzianum

hyphae lysed about $25 \%$

G. boninense hyphae lysed about $90 \%$

and hyphae tended to become small

G. boninense hyphae lysed about $50 \%$ starting from the tip of hyphae. T. harzianum hyphae lysed about $10 \%$

G. boninense hyphae lysed about $25 \%$, the tips of hyphae were normal. $T$. viride hyphae lysed about $25 \%$

G. boninense hyphae lysed about $25 \%$, the tips of hyphae were normal. $T$. viride hyphae lysed about $10 \%$

G. boninense hyphae lysed about $90 \%$, and hyphae tended to become small. $T$. viride hyphae lysed about $25 \%$ 
GD, T. harzianum BIO-2 vs. G. boninense isolates GA and GD, T. viride vs. $G$. boninense isolates GA, GB and GD.

In general T. harzianum BIO - 1 had the same effectivity score against the three pathogen isolates. The ef fectivity score of $T$. harzianum BIO - 2 and $T$. viride was determined by the type of isolate of the pathogen.

If we look at either the percentage of inhibition of mycelial growth of the pathogen by the antagonist or the capability of the antagonist to cause hyphal lyses of the pathogen, $T$. harzianum BIO- 1 was the most potential antagonist. Chet et al. (1979) found that $T$. harzianum could control damping-off disease on bean, peanuts and egg plants caused by Sclerotium rolfsii and Rhizoctonia solani. Sivan and Chet (1986) also found that $T$. harzianum could control Fusarium spp. in cotton, wheat and muskmelon.

\section{CONCLUSION}

P. citrinum, T. harzianum (isolate BIO- 1 and BIO-2), and T. viride isolated from oil palm plantation in North Sumatra were antagonistic to G. boninense. T. harzianum isolate BIO - 1 was the most potential antagonist. $P$. citrinum probably produces an antibiotic substance that diffuses into the medium, while Tricho-derma causes lyses of the pathogen's hyphae.

\section{ACKNOWLEDGMENTS}

The authors gratefully acknowledge the funds given by Marihat Research Center, Pematang Siantar, North Sumatra. Thanks are also due to Dr. R.A. Samson of Central Bureau voor Schimmelcultures (CBS), Baarn, The Netherlands, and Dr. M.A. Rifai of the Research Centre for Development in Biology, Indonesian Institute of Science, Bogor, Indonesia, in having confirmed the identification of the fungal isolates.

\section{REFERENCES}

CHET, I., Y. HADAR, Y. ELAD, J. KATAN and Y. HENIS. 1979. Biological control of soil-borne plant pathogens by Trichoderma harzianum. In SCHIPPERS, B. and W. GAMSA (eds.). Soil-borne plant pathogens. Academic Press, London: 585-591.

COOK, R.J. and K.F. BAKER. 1983. The nature and practice of biological control of plant pathogens. The American Phytopathological Society, St. Paul, Minnesota. 
Antagonistic effect of four fungal isolates-O.S. Dharmaputra, H.S.S. Tjitrosomo \& A.L. Abadi

DENNIS, C. and J. WEBSTER. 1971. Antagonistic properties of species groups of Trichoderma. III. Hyphal interaction. Trans. Brit. Mycol. Soc. 57: 363-369.

FOKKEMA, N.J. 1973. The role of saprophytic fungi in antagonism against Drechslera sorokiniana (Helminthosporium sativurri) on agar plates and on rye leaves with pollen. Physiological Plant Pathology 3: 195-205.

PARNATA, Y. 1974. Control of basal stem rot of oil palm using urea in accelerating stem and stump decay. Bulletin Balai Penelitian Perkebunan Medan 5(3): 89-94.

SIPAYUNG, A. and R.Y. PURBA. 1986. Penelitian dan usaha penanggulangan penyakit busuk pangkal batang (Ganodermd) di perkebunan kelapa sawit (Research and control of basal stem rot (Ganoderma sp.) in oil palm plantation). Special edition. PT Perkebunan VI-VII, Marihat Research Center, Marihat Ulu, Pematang Siantar.

SIVAN, A. and I. CHET. 1986. Biological control of Fusarium spp. in cotton, wheat and muskmelon by Trichoderma harzianum. J. Phytopathology 116: 39-47.

SUYOTO, S. and A. DJAMIN. 1981. Sistem pemberantasan penyakit busuk pangkal batang (Ganodermd) di perkebunan kelapa sawit PTP VI. (System of controlling basal stem rot (Ganodermd) in oil palm plantation PTP VI). Paper presented at $6^{\text {th }}$ Indonesian Phytopathology Society Congress, Bukittinggi. 